\title{
Bio Module for the Management of Root Knot Nematode (Meloidogyne incognita) Infected with Tomato under Precision Farming System
}

\author{
P. Senthilkumar ${ }^{1}$ and S. Prabhu ${ }^{2} *$ \\ ${ }^{1}$ Regional Research Station, TNAU, Paiyur, India \\ ${ }^{2}$ Department of Plant protection, Horticutlural College and Research Institute, \\ Periyakulam - 625604, India \\ *Corresponding author
}

Keywords

Root knot nematode, Tomato. Bio management, Meloidogyne incognita

\section{Article Info}

Accepted:

10 March 2020

Available Online:

10 April 2020

\section{A B S T R A C T}

Root-knot nematodes (RKN) have more than 3000 species of potential host range. The majority of the damage to crop plants is caused by Meloidogyne incognita. This experiment investigates the development of standard module for the management of root knot nematode tomato grown under precision farming system; Application of bio nematicides suppressed the pathogenic effect of root knot nematode and significantly reduced gall index and population density of $M$. incognita in roots and soil. Highest reduction in soil (71.26) and root population (22.38) of root knot nematode, M. incognita was observed in Purpureocillium lilacinum (root dip) + Trichoderma asperellum (2 kg/ha)+ Marigold intercrop treated plot at time of harvest. The control plot recorded maximum population of nematodes in soil and root respectively 1252.54 and 1224.88. The roots in untreated control recorded the highest gall index of 5.00. Significant increase in tomato yield was observed in all the plants treated with biocides. However, highest tomato yield $(3.1 \mathrm{Kg} / \mathrm{plot})$ was observed in the treatment with P. lilacinus (root dip) $+T$. asperellum $(2 \mathrm{~kg} / \mathrm{ha})+$ Marigold intercrop. It also recorded the highest cost benefit ratio of 1:2.2. While the untreated control plants recorded the lowest yield of $2.1 \mathrm{Kg} /$ plot.

\section{Introduction}

Tomato (Solanum lycopersicum L.) is one of most important and largest vegetable crop in the world. In India contribute about nine percent share in world production and most important vegetables grown in Tamil Nadu. Major production area in Tamil Nadu growing tomato is Coimbatore, Dharmapuri, Salem and Krishnagiri districts. Root-knot nematodes (RKN) have more than 3000 species a potential wide host range (Abad et al., 2003). The majority of crop damage is caused by $M$. incognita, both in tropical and temperate climates. The damage to the root system caused by the nematodes 
compromised nutrient and water uptake leading to weak plants with poor root system and yields (Abad et al., 2003). Nonavailability of chemical nematicides increased costs of management practices and hazardous nature of chemical leads to use of eco-friendly bio nematicides. In India an average loss of Rs. 21,068.73 million has been estimated due to plant parasitic nematodes. An overall average annual yield loss in major horticultural crops due to nematodes goes up to $60 \%$ under protected cultivation.

\section{Materials and Methods}

The field experiment was conducted at farm of RRS, Paiyur during the period of 20182019 for assessment effects of bio agents against, Meloidogyne incognita in tomato. Tomato PKM 1 seedling was planted at field of RRS, Paiyur with the spacing of $60 \times 45 \mathrm{~cm}$ and the plot size of $10 \mathrm{~m}^{2}$. Bioagents and chemicals were collected from farm of RRS and treated with plot. Bioagents Purpureocillium lilacinum treated in seedlings as root dip and Trichoderma asperellum $2 \mathrm{~kg} / \mathrm{ha}$ was applied in experimental plot mixed with FYM.

After three months, the plants were uprooted, washed and the growth parameters viz., plant length, fresh weight of shoot and root and fruit weight were assessed. The number of plants with galled root system and the rootknot index were expressed on a $0-5$ scale $(0=$ no galling; $1=1-2$ galling; $2=3-10$ galling; 3 =11-30 galling; 4 = 31-100 galling; and $5=$ more than 100 galling per root system) (Heald et al., 1989).

The nematode population in the soil was determined by Cobb's sieving and decanting method, followed by the modified Baermann funnel technique (Southey, 1986). Number of adult females within the roots examined by staining using lactic acid-fuchsin technique
(Byrd et al., 1983). The number of females within the root segment was determined using dissecting microscope (x 40). The total number of adult females present in root was calculated by multiplying the number of adult females present in $5 \mathrm{~g}$ of root by the total weight of root. This data was analyzed using one way ANOVA in SPSS 12.00 software (SPSS Inc., Chicago, IL, USA) and means compared using the LSD test.

\section{Results and Discussion}

The highest reduction in soil and root population soil (71.26) and root population (22.38) of root knot nematode, M.incognita was observed in $P$. lilacinum (root dip) $+T$. asperellum (2 kg/ha) + Marigold intercrop treated plots. The control plot recorded lowest population of nematodes in soil and root respectively 1252.54 and 1224.88 (Table 1).

Lowest root knot index was observed in the bioagent P.lilacinum (root dip) $+T$. asperellum (2 kg/ha)+ Marigold intercrop treated plots. Untreated control plant root recorded the highest lesion index of 5.00 (Table 2).

Significant increase in tomato yield was observed in all the plants treated with biocides. However, highest tomato yield (3.1 $\mathrm{Kg} / \mathrm{plot}$ ) was observed in the treatment with $P$. lilacinum (root dip) $+T$. asperellum (2 $\mathrm{kg} / \mathrm{ha})+$ Marigold intercrop. The application of same treatment recorded the highest cost benefit ratio of 1:2.2.

While the untreated control plants recorded the lowest yield of $2.1 \mathrm{Kg} /$ plot (Table 2). Even though the per cent reduction of nematode is more in carbofran treated plants when compared to bio nematicide combinations (Fig. 1) the B:C ration is high in combination treatment and the damage to environment is also less. 
Table.1 Assessment of morphmetric characters, status of galls and egg masses in tomato var.(PKM1) treated with various components against root knot nematode

\begin{tabular}{|c|c|c|c|c|c|c|c|}
\hline Treatments & $\begin{array}{c}\text { Root } \\
\text { length }(\mathbf{c m})\end{array}$ & $\begin{array}{c}\text { Root } \\
\text { weight }(\mathrm{cm})\end{array}$ & $\begin{array}{l}\text { Shoot length } \\
(\mathrm{cm})\end{array}$ & $\begin{array}{l}\text { Shoot weight } \\
\text { (g) }\end{array}$ & $\begin{array}{l}\text { No of galls } \\
\text { /root system }\end{array}$ & $\begin{array}{l}\text { No of egg } \\
\text { masses /gall }\end{array}$ & $\begin{array}{l}\text { No of eggs } \\
\text { /egg masse }\end{array}$ \\
\hline $\begin{array}{c}T_{1}-T \text {. asperellum }(2 \mathrm{~kg} / \mathrm{ha})+\text { Neem } \\
\text { cake } 500 \mathrm{~kg} / \mathrm{ha}+\text { Marigold } \\
\text { intercrop }\end{array}$ & $\begin{array}{l}23.36 \\
(4.88)\end{array}$ & $\begin{array}{r}170.32 \\
(13.07)\end{array}$ & $\begin{array}{l}65.84 \\
(8.14)\end{array}$ & $\begin{array}{r}190.24 \\
(13.81)\end{array}$ & $\begin{array}{r}102.44 \\
(10.15)\end{array}$ & $\begin{array}{l}44.84 \\
(6.73)\end{array}$ & $\begin{array}{l}215.46 \\
(14.69)\end{array}$ \\
\hline $\begin{array}{c}T_{2} \text {-Purpureocillium lilacinum(root } \\
\text { dip)+T. asperellum( }(2 \mathrm{~kg} / \mathrm{ha})+ \\
\text { Marigold intercrop }\end{array}$ & $\begin{array}{l}32.42 \\
(5.74)\end{array}$ & $\begin{array}{l}225.24 \\
(15.02)\end{array}$ & $\begin{array}{l}81.28 \\
(9.04)\end{array}$ & $\begin{array}{l}240.84 \\
(15.53)\end{array}$ & $\begin{array}{l}44.48 \\
(9.22)\end{array}$ & $\begin{array}{l}12.21 \\
(5.72)\end{array}$ & $\begin{array}{l}102.24 \\
(10.14)\end{array}$ \\
\hline $\begin{array}{c}\text { T}_{3} \text {-Carbofuran 3G @ 1kg a.i./ha)+ } \\
\text { Marigold intercrop }\end{array}$ & $\begin{array}{l}18.44 \\
(4.35)\end{array}$ & $\begin{array}{l}150.46 \\
(12.27)\end{array}$ & $\begin{array}{l}52.88 \\
(7.30)\end{array}$ & $\begin{array}{l}160.24 \\
(12.66)\end{array}$ & $\begin{array}{l}124.78 \\
(11.18)\end{array}$ & $\begin{array}{l}50.24 \\
(7.11)\end{array}$ & $\begin{array}{l}170.24 \\
(13.05)\end{array}$ \\
\hline $\mathbf{T}_{4}$-Untreated control & $\begin{array}{l}13.24 \\
(3.71)\end{array}$ & $\begin{array}{l}101.44 \\
(10.09)\end{array}$ & $\begin{array}{l}36.54 \\
(6.09)\end{array}$ & $\begin{array}{l}122.44 \\
(11.09)\end{array}$ & $\begin{array}{l}218.66 \\
(14.80)\end{array}$ & $\begin{array}{l}105.44 \\
(10.29)\end{array}$ & $\begin{array}{l}354.24 \\
(18.83)\end{array}$ \\
\hline CD $(p=0.05)$ & 2.08 & 3.38 & 2.64 & 3.47 & 3.21 & 2.61 & 3.58 \\
\hline SED & 0.95 & 1.55 & 1.24 & 1.59 & 1.47 & 1.20 & 1.64 \\
\hline
\end{tabular}

Table.2 Assessment of nematode population and yield in tomato var.(PKM1) treated with various components against root knot Nematode

\begin{tabular}{|c|c|c|c|c|c|}
\hline Treatment & $\begin{array}{c}\text { Soil nematode } \\
\text { population at } \\
\text { harvest }\end{array}$ & $\begin{array}{l}\text { Root population } \\
\text { at harvest }\end{array}$ & $\begin{array}{l}\text { Root knot } \\
\text { index \% }\end{array}$ & Yield kg /plot & $\mathbf{B}: \mathbf{C}: \mathbf{R}$ \\
\hline $\begin{array}{c}\mathrm{T}_{1-} \text { T. asperellum }(2 \mathrm{~kg} / \mathrm{ha})+\text { Neem cake } 500 \mathrm{~kg} / \mathrm{ha}+ \\
\text { Marigold intercrop }\end{array}$ & $\begin{array}{l}454.48 \\
(6.12)\end{array}$ & $\begin{array}{l}387.44 \\
(5.96)\end{array}$ & $\begin{array}{c}3.5 \\
(1.25)\end{array}$ & $\begin{array}{c}2.5 \\
(0.92)\end{array}$ & $1: 1.2$ \\
\hline $\begin{array}{c}T_{2} \text {-Purpureocillium lilacinum }(\text { root } \operatorname{dip})+T \text {. } \\
\text { asperellum }(2 \mathrm{~kg} / \mathrm{ha})+\text { Marigold intercrop }\end{array}$ & $\begin{array}{l}71.26 \\
(4.27)\end{array}$ & $\begin{array}{l}22.38 \\
(3.11)\end{array}$ & $\begin{array}{c}1.2 \\
(0.18)\end{array}$ & $\begin{array}{c}3.1 \\
(1.13)\end{array}$ & $1: 2.2$ \\
\hline T3-Carbofuran 3G @1kg a.i./ha & $\begin{array}{l}354.24 \\
(5.87)\end{array}$ & $\begin{array}{l}275.44 \\
(5.62)\end{array}$ & $\begin{array}{c}3.2 \\
(1.16)\end{array}$ & $\begin{array}{c}2.8 \\
(1.03)\end{array}$ & $1: 2.0$ \\
\hline T4-Untreated control & $\begin{array}{c}1252.54 \\
(7.13)\end{array}$ & $\begin{array}{c}1224.88 \\
(7.11)\end{array}$ & $\begin{array}{c}5.0 \\
(1.61)\end{array}$ & $\begin{array}{c}2.1 \\
(0.74)\end{array}$ & \\
\hline CD $(p=0.05)$ & 1.53 & 1.40 & 0.21 & 0.31 & \\
\hline SEd & 0.88 & 0.72 & 0.02 & 0.15 & \\
\hline
\end{tabular}

Figures in the parenthesis is log transformed values 


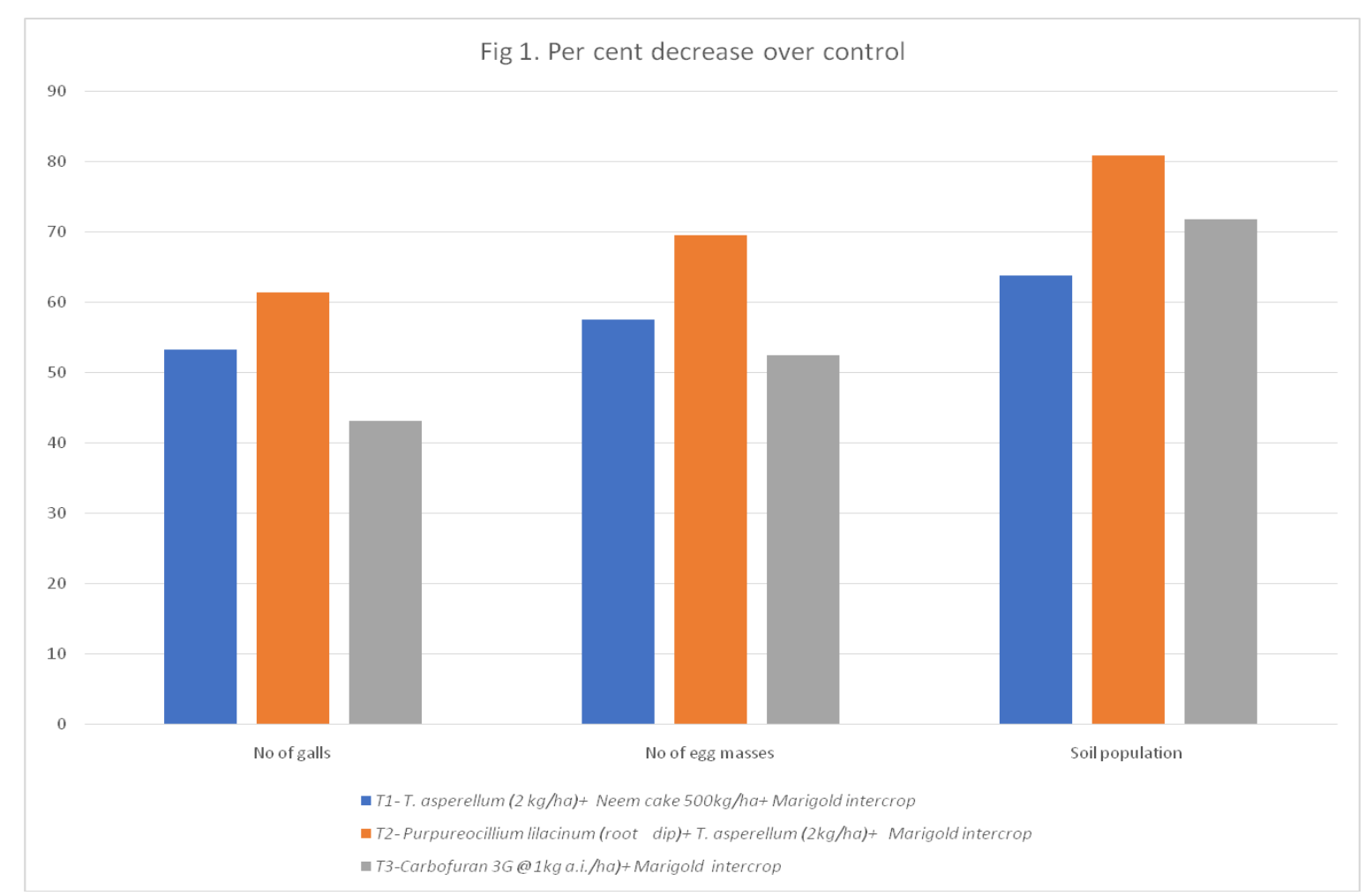

Fig.1 Per cent decrease over control

There are several reports in which the combination of these two fungal bioagents $P$. lilacinumis parasitic (Azam et al., 2009) and the other $T$. asperellum egg parasite and fungal biocontrol have more potential against M. Incognita with better plant growth parameters.

In addition, it is also clear from Tables 1 and 2, was addition of both, $P$. lilacinum $+T$. asperellum significantly most promising when compared to other combinations. This response is attributed due to the growth promotion characteristics of $T$. asperellum, which also improve the overall plant health.

This combination show excellent nematicidal activity and also reducing major soil borne diseases (Batten and Powell 1971). Further, this combination reduces the disease complex caused by the root knot nematode this could be proposed as an ideal component of an integrated pest management package under precision farming system of tomato cultivation.

\section{References}

Abad, P., Favery, B., Rosso, M.N. \& Castagone-Sereno, P. (2003). Root-knot nematodeparasitism and host response: Molecular basis of a sophisticated interaction. Mol. Plant Pathol., 4: 217224.

Azam, T., Hisamuddin and Singh, S. (2009). Efficacy of plant leaf powder and Paecilomyces lilacinus alone and in combination for controlling Meloidogyne incognita on chickpea. Indian Journal of Nematoogy.39: 152155.

Byrd, D.W., Kirkpatrick, T. \& Barker, K. (1983). An improved technique for clearing and staining plant tissues for detection of nematodes. J. Nematol., 15: 142-143. 
Heald, C.M. Briton, B.D. and Davis R.M.1989. Influence of Glomus intraradices and soil phosphorus on

Meloidogyne incognita infecting Cucumis melo Journal of Nematology, 21: 69-73.
Southey, J.F. (1986). Laboratory methods for work with plant and soil nematodes: Ministry of Agriculture, Fisheries and Food, HMSO, London, 202 pp.

\section{How to cite this article:}

Senthilkumar, P., and Prabhu, S. 2020. Bio Module for the Management of Root Knot Nematode (Meloidogyne incognita) Infected with Tomato under Precision Farming System. Int.J.Curr.Microbiol.App.Sci. 9(04): 1196-1200. doi: https://doi.org/10.20546/ijcmas.2020.904.141 